\title{
Correction to: A comparative study of parental knowledge and adaptation of immigrant youth
}

\author{
Elina Turjanmaa ${ }^{1 *}$ and Inga Jasinskaja-Lahti ${ }^{2}$
}

The original article can be found online at https://doi.org/10.1186/ s40878-020-00207-z.

*Correspondence: elina.turjanmaa@ oulu.fi

${ }^{1}$ Research Unit for History, Culture and Communications, University of Oulu, PO Box 1000, Fl-900014 Oulu, Finland

Full list of author information is available at the end of the article

\section{Correction to: Comparative Migration Studies 8, 47 (2020)}

https://doi.org/10.1186/s40878-020-00207-z

Following publication of the original article (Turjanmaa \& Jasinskaja-Laht, 2020), the authors would like to the last sentence of the sixth paragraph of the 'Discussion' section.

The sentence originally read:

Disclosure of adolescents may also be seen as an adaptive strategy that is used in order to increase adolescents' autonomy in relation to their parents (Yau 2016).

The sentence should read (the change has been highlighted in bold typeface):

Nondisclosure of adolescents may also be seen as an adaptive strategy that is used in order to increase adolescents' autonomy in relation to their parents (Yau 2016).

The original article (Turjanmaa \& Jasinskaja-Laht, 2020) has been corrected.

\section{Author details}

'Research Unit for History, Culture and Communications, University of Oulu, PO Box 1000, Fl-900014 Oulu, Finland.

${ }^{2}$ University of Helsinki, Helsinki, Finland.

Published online: 07 April 2021

\section{Reference}

Turjanmaa, E., \& Jasinskaja-Laht, I. (2020). A comparative study of parental knowledge and adaptation of immigrant youth Comparative Migration Studies, 8. https://doi.org/10.1186/s40878-020-00207-z.

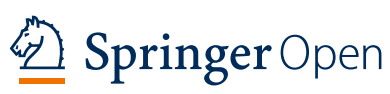

(ㅇ The Author(s). 2021 Open Access This article is licensed under a Creative Commons Attribution 4.0 International License, which permits use, sharing, adaptation, distribution and reproduction in any medium or format, as long as you give appropriate credit to the original author(s) and the source, provide a link to the Creative Commons licence, and indicate if changes were made. The images or other third party material in this article are included in the article's Creative Commons licence, unless indicated otherwise in a credit line to the material. If material is not included in the article's Creative Commons licence and your intended use is not permitted by statutory regulation or exceeds the permitted use, you will need to obtain permission directly from the copyright holder. To view a copy of this licence, visit http://creativecommons.org/licenses/by/4.0/. 